\title{
Cellphone and media usage among adolescent girls of Bhopal city, Madhya Pradesh, India
}

\author{
Purva Singh*, Manisha Jain
}

Department of Obstetrics and Gynecology, Peoples College of Medical Sciences and Research Centre, Bhopal, Madhya Pradesh, India

Received: 06 April 2017

Accepted: 02 May 2017

*Correspondence:

Dr. Purva Singh,

E-mail: dr.purva19@gmail.com

Copyright: () the author(s), publisher and licensee Medip Academy. This is an open-access article distributed under the terms of the Creative Commons Attribution Non-Commercial License, which permits unrestricted non-commercial use, distribution, and reproduction in any medium, provided the original work is properly cited.

\begin{abstract}
Background: Several researchers have reported that mobile phone uses are increasing among adolescents. Better understanding of cellphone and media usage by adolescents would help health care providers in guiding more responsible use of cellphone by teenagers. Aim of the study was to study the level and pattern of mobile phone usages among adolescent girls of Bhopal city, Madhya Pradesh.

Methods: This cross-sectional study was conducted among adolescent girls between 14 to 19 years of age studying in schools of Bhopal city. Data was collected using a self-administered questionnaire. The questionnaire contains items related to demographic variables, cellular phone usage and patterns.

Results: All the study subjects were using smart phones. Facebook was the most commonly surfed website. Maximum adolescent girls were using smartphones for 2-4 hours in a day. Seventy-eight (69.03\%) study subjects preferred text messaging service for awareness about reproductive and sexual health.

Conclusions: The cellphone usage can also be exploited to promote awareness about reproductive health among adolescents.
\end{abstract}

Keywords: Adolescents, Cell-phone, Health, Mobile phone, Technology

\section{INTRODUCTION}

In recent years, wireless devices such as cell phones, pagers and pocket PCs have gained popularity among a wide variety of users. ${ }^{1}$ Use of smart phones has exploded and has become an essential part of business, commerce and society. ${ }^{2}$ Smartphone technology provides immense benefits for users as they access and disseminate information rapidly. ${ }^{3}$

Several researchers have reported that mobile phone uses are increasing among adolescents. ${ }^{3,4}$ According to the American society of Addiction Medicine, Addiction is a primary, chronic disease of brain reward, motivation, memory and related circuitry. Dysfunction in these circuits leads to characteristic biological, psychological, social and spiritual manifestations. This is reflected in an individual pathologically pursuing reward and/or relief by substance use and other behaviors. Nowadays, addiction not only refers to drug or substance abuse, but it also refers to gambling, internet, games, or even smart phones. ${ }^{4}$

The smart phone usage not only has a behavioral impact on adolescents but can also affect their holistic development. Teens may face several barriers to accessing reliable, useful, and age-appropriate information and services for their health. Increasing use of smart phones can be taken as positive tool for health promotion. ${ }^{5}$ The use of text messaging is an innovative way to engage teens in preventive health learning and practices. $^{6}$ 
Better understanding of cellphone and media usage by adolescents would help health care providers and parents in guiding more responsible use of cellphone by teenagers. However, no such studies have been reported from central India. Hence, present research was conducted to study the level and pattern of mobile phone usages among adolescent girls. Also, association of mobile phone usage was evaluated with various sociodemographic variables.

\section{METHODS}

The present cross-sectional, questionnaire based study was conducted by the department of Obstetrics and Gynaecology, People's College of Medical Sciences and Research Center, Bhopal, Madhya Pradesh. The study population included adolescent girls between 14 to 19 years of age studying in schools of Bhopal city. Study subjects were recruited by convenient sampling from two English medium schools of Bhopal city. All the adolescent girls present on the day of study were taken as study subjects. The study subjects were explained about study objectives. Also, they were assured about anonymity and could opt out the study at any point of time.

Data was collected using a self-administered questionnaire. The questionnaire contains items related to demographic variables, cellular phone usage and patterns among adolescents. The questionnaire was first pre-tested among twenty adolescent girls. Also, the contents of questionnaire were scrutinized by a panel of three academicians. After this necessary change were made to prepare a revised and final version of the questionnaire. Participation in the study was voluntary. The verbal consent was obtained from participants. Ethical clearance for the study was obtained from ethical committee of People's College of Medical Sciences and Research Center, Bhopal, Madhya Pradesh, India. For statistical analysis, data collected was entered in Microsoft excel 2013 for Windows. Frequency and percentages of responses were calculated using version 21.0 of the Statistical Package for Social Sciences (IBM Corporation, Armonk, New York, USA).

\section{RESULTS}

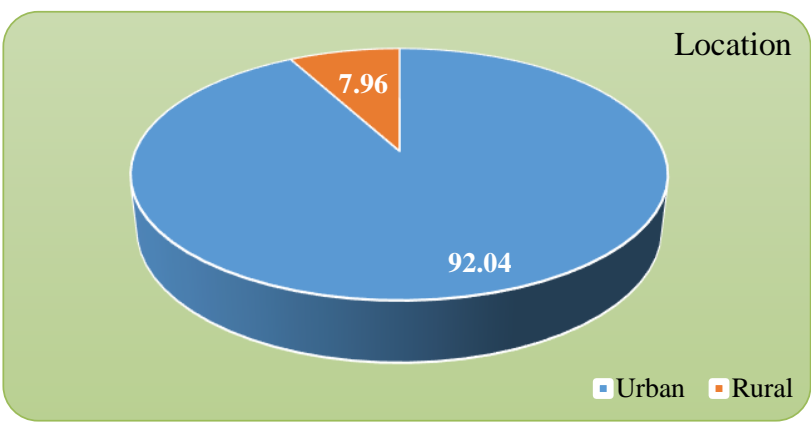

Figure 1: Distribution of study population according to geographic location (in percentage).
A total of 113 adolescent girls consented to participate in the study. The questionnaire distributed among these study subjects were completely filled, hence response rate was $100 \%$. Among them 104 (92.04\%) belong to urban area and remaining $09(7.96 \%)$ belong to rural area (Figure 1). Age wise distribution showed that 15 (13.27\%) belong to $10-14$ years and $98(86.73 \%)$ belong to $15-18$ years (Figure 2).

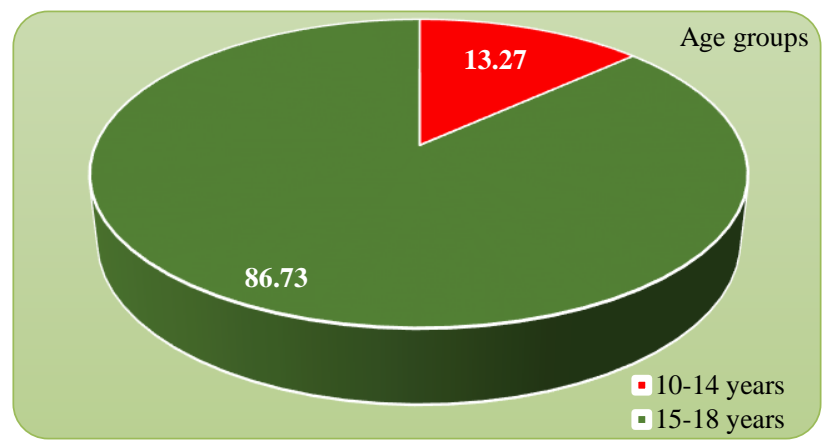

Figure 2: Age wise distribution of study population (in percentage).

All the study subjects were using smart phones $(100.00 \%)$ followed by use of laptops (38.05\%) and tablets $(5.31 \%)$ (Table 1). Eighty-three $(73.45 \%)$ adolescent girls were using these devices under parental supervision (Figure 3).

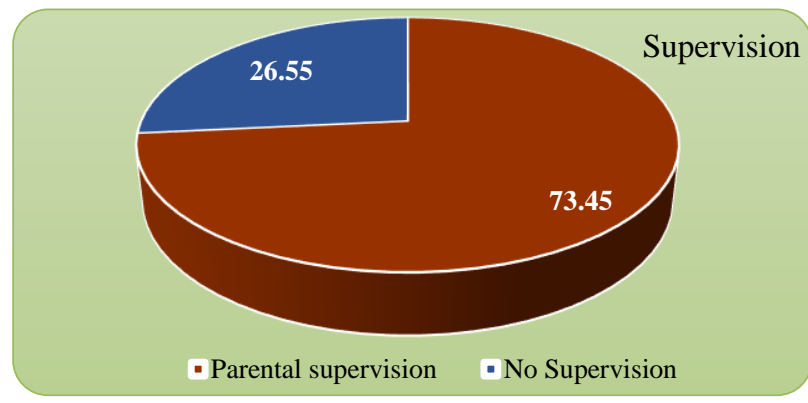

Figure 3: Type of supervision on usages of devices (in percentage).

Facebook was the most commonly surfed website 75 (66.37\%), followed by Google 43 (38.05\%) and Whatsapp $30(26.55 \%)$ (Table 2).

Table 1: Usages of various devices by study population.

\begin{tabular}{|ll|l|}
\hline Devices & $\begin{array}{l}\text { Number of } \\
\text { study subjects }\end{array}$ & $\begin{array}{l}\text { Percentage of } \\
\text { study subjects }\end{array}$ \\
\hline Smart phones & 113 & 100.00 \\
\hline Laptops & 43 & 38.05 \\
\hline Tablets & 06 & 5.31 \\
\hline
\end{tabular}

Nearly $93 \%$ were using these websites for communication, $88.50 \%$ for chatting and $67.26 \%$ for surfing (Table 3). 
Table 2: Most commonly surfed websites by study population.

\begin{tabular}{|lll|}
\hline Websites & $\begin{array}{l}\text { Number of } \\
\text { study subjects }\end{array}$ & $\begin{array}{l}\text { Percentages of } \\
\text { study subjects }\end{array}$ \\
\hline Facebook & 75 & 66.37 \\
\hline Google & 43 & 38.05 \\
\hline Whatsapp & 30 & 26.55 \\
\hline
\end{tabular}

Table 3: Usages of websites by study population.

\begin{tabular}{|l|l|l|}
$\begin{array}{l}\text { Usages of } \\
\text { websites }\end{array}$ & $\begin{array}{l}\text { Number of } \\
\text { study subjects }\end{array}$ & $\begin{array}{l}\text { Percentages of } \\
\text { study subjects }\end{array}$ \\
\hline Communication & 105 & 92.92 \\
\hline Chatting & 100 & 88.50 \\
\hline Surfing & 76 & 67.26 \\
\hline
\end{tabular}

Maximum adolescent girls (44.25\%) were using smartphones for 2-4 hours (Table 4).

Table 4: Smartphone usages by study population according to time duration.

\begin{tabular}{|lll|}
\hline Hours/day & $\begin{array}{l}\text { Number of } \\
\text { study subjects }\end{array}$ & $\begin{array}{l}\text { Percentage of } \\
\text { study subjects }\end{array}$ \\
\hline 1 hour & 07 & 6.19 \\
\hline $2-4$ hours & 50 & 44.25 \\
\hline $4-8$ hours & 25 & 22.12 \\
\hline$>8$ hours & 31 & 27.43 \\
\hline
\end{tabular}

Seventy-eight $(69.03 \%)$ study subjects preferred text messaging service for awareness about reproductive and sexual health. However, $27(23.89 \%)$ did not prefer and $08(7.08 \%)$ were not sure (do not know) (Figure 4).

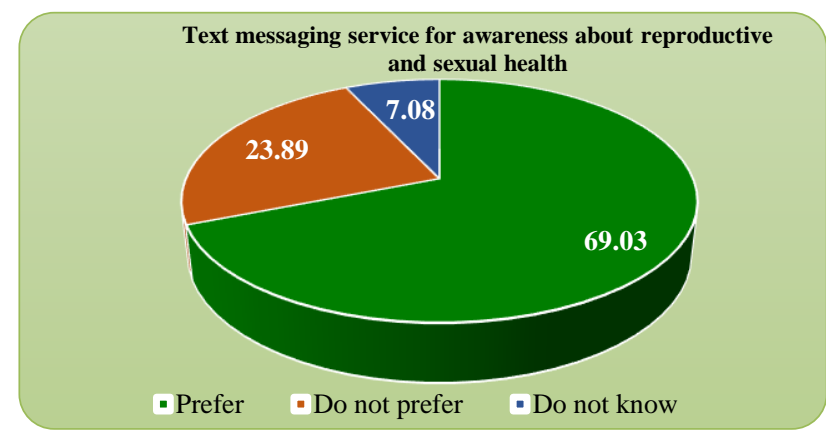

Figure 4: Preference for text messaging service for awareness about reproductive and sexual health (in percentage).

\section{DISCUSSION}

Wireless technologies now cover $96 \%$ of the global population and penetrate all walks of life. With 6.8 billion mobile-cellular subscriptions worldwide, the technology has successfully bridged gaps in communication and ignited economic growth and development globally. ${ }^{7}$ In present study all the study subjects were using smart phones. With 877 million wireless subscribers, India has the second largest wireless communication subscriber base in the world. Wireless subscribers comprise $96 \%$ of telecom subscribers in India and contribute to an urban wireless tele-density fourfold that of rural India. One of the reasons for the popularity of mobile phones in India is the low call tariff. At 1.6 $\mathrm{USD} / \mathrm{month}$, India has one of the lowest mobile call tariffs globally. This makes mobile phone communication economical in the Indian context. ${ }^{7}$

In the present study, maximum adolescent girls (44.25\%) were using smartphones for 2-4 hours. Given the everincreasing amount of time people spend using technology, and the potentially deleterious effects such increases can have on quality of life, the present study's investigation of cell-phone use is critically important. In a study Roberts et al. found that women reported spending an average of 600 minutes on a cell-phone every day compared to 459 minutes for males. ${ }^{8}$

Several studies have reported the adverse effects of excessive usage of mobile phones. In a study by Zheng et al., the strongest association between inattention and the time spent on the mobile phones was among students who spent more than 60 minutes per day playing on their mobile phones. ${ }^{9}$

According to Thomee, spending more than two hours daily for emailing and chatting was related crosssectionally to overweight in the women. ${ }^{10}$ Nearly $93 \%$ adolescent girls in the present study were using websites for communication. In a study Roberts et al. observed that desire to connect socially was a major reason to use cell- phones. ${ }^{8}$

Majority of study subjects in present research preferred text messaging service for awareness about reproductive and sexual health. In a study Gerber et al. has demonstrated feasibility and acceptability of text messaging as a method for promoting healthy behaviors. ${ }^{6}$ The mobile phone, as a tool for receiving health information and supporting healthcare through mHealth interventions was acceptable in the rural Indian context. ${ }^{7}$

\section{CONCLUSION}

In conclusion, the cellphone usage among adolescent girls has almost become a universal phenomenon. Proper parental guidance and support by health care providers can help judicious use of cellphone by adolescents.

The cellphone usage can also be exploited to promote awareness about reproductive health among adolescents. Through text messaging, participants will feel that they have a level of privacy that is not offered through other forms of health communication or health education. With so many aspects of their daily lives revolving around mobile phones, it is possible that teens may be receptive to mobile phone-based interventions that involve health topics geared toward their age-group. 
Funding: No funding sources

Conflict of interest: None declared

Ethical approval: The study was approved by the

Institutional Ethics Committee

\section{REFERENCES}

1. Aoki K, Downes EJ. An analysis of young people's use of and attitudes toward cell phones. Telematics and Informatics. 2003;20:349-64.

2. Jamal A, Sedie R, Haleem KA, Hafiz N. Patterns of use of 'smart phones' among female medical students and self-reported effects. J Taibah Universit Medic Sci. 2012;7(1):45-9.

3. Alson JN, Misagal LV. Smart phones usage among college students. Internat $\mathbf{J}$ Res Eng Technol. 2016;4(3):63-70.

4. Kumar KASS. Mobile phone and adolescentsaddiction a mindful check in. Internat $\mathrm{J}$ Advanced Nursg Stud. 2014;3(1):42-6.

5. Valk JH, Rashid AT, Elder L. Using mobile phones to improve educational outcomes: an analysis of evidence from Asia. International Review of Research in Open and Distance Learning. 2010;11(1):117-40.

6. Gerber BS, Stolley MR, Thompson AL, Sharp LK, Fitzgibbon ML. Mobile phone text messaging to promote healthy behaviors and weight loss maintenance: a feasibility study. Health Informatics J. 2009;15(1):17-25.

7. DeSouza SI, Rashmi MR, Vasanthi AP, Joseph SM, Rodrigues R. Mobile phones: the next step towards healthcare delivery in rural India? PLoS One. 2014;9(8):e104895.

8. Roberts JA, Yaya LHP, Manolis C. The invisible addiction: Cell-phone activities and addiction among male and female college students. J Behav Addict. 2014;3(4):254-65.

9. Zheng F, Gao P, He M, Li M, Wang C, Zeng Q, et al. Association between mobile phone use and inattention in 7102 Chinese adolescents: a population-based cross-sectional study. BMC Public Health. 2014;14:1022.

10. Thomee S, Lissner L, Hagberg M, Grimby-Ekman A. Leisure time computer use and overweight development in young adults-a prospective study. BMC Public Health. 2015;15:839.

Cite this article as: Singh P, Jain M. Cellphone and media usage among adolescent girls of Bhopal city, Madhya Pradesh, India. Int J Reprod Contracept Obstet Gynecol 2017;6:3861-4. 